\title{
WHAT INNOVATION MEANS FOR THE ADOPTION OF ECO-INNOVATION IN A CHEMICAL COMPANY?
}

\author{
O QUE A INOVAÇÃO SIGNIFICA PARA A ADOÇÃO DA \\ ECOINOVAÇÃO EM UMA EMPRESA QUIIMICA?
}

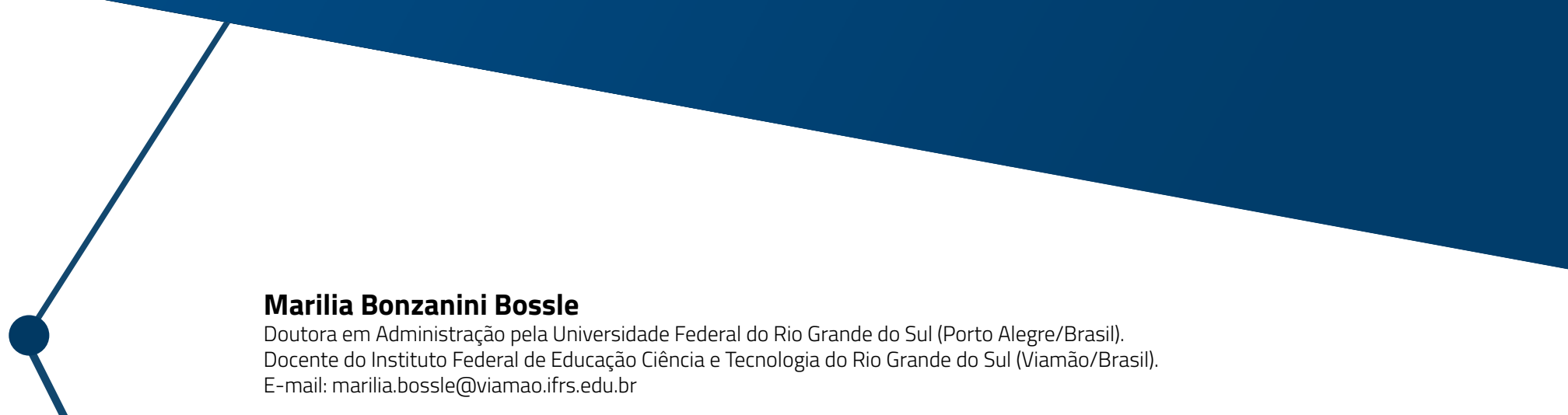

\section{Claudia Cristina Bitencourt}

Doutora em Administração pela Universidade Federal do Rio Grande do Sul (Porto Alegre/Brasil).

Docente da Universidade do Vale do Rio dos Sinos - UNISINOS (São Leopoldo/Brasil).

E-mail: claudiacb@unisinos.br

\section{Cristiane Froehlich}

Doutora em Administração pela Universidade do Vale do Rio dos Sinos (São Leopoldo/Brasil).

Docente e Pesquisadora do Instituto de Ciências Sociais e Aplicadas da Universidade Feevale (Novo Hamburgo/Brasil).

E-mail: ecfroehlich@feevale.br

\section{Gabriela Zanandrea}

Doutora em Administração pela Universidade de Caxias do Sul (Caxias do Sul/Brasil).

E-mail: gabi.zanandrea@gmail.com

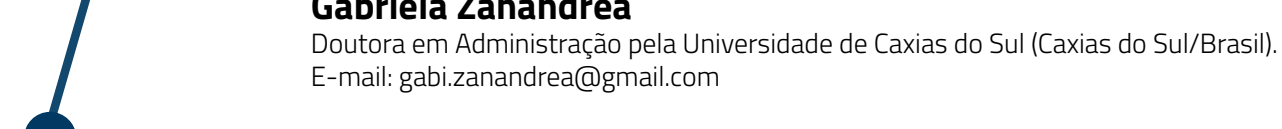




\section{ABSTRACT}

There are internal and external factors that influence companies on the implementation of eco-innovation. This article aims to analyze what leads a chemical company from an emerging country to adopt ecoinnovation. We developed a qualitative case study based on external and internal factors. The results indicate that the company focused mainly on Research and Development (R\&D) and product innovation, emphasizing that innovation can bring advantages in the integration of eco-innovation in its processes. In relation to the drivers for adopting eco-innovation, the influence is more external, based on normative pressures, cooperation and technology. The main challenge is to align sustainable concepts with company strategy, while integrating innovation across departments, this did not drive eco-innovation strategies. Background research on eco-innovation can help policymakers guide and predict corporate behavior and develop mechanisms to encourage environmental management.

Keywords: Eco-Innovation. Chemical Industry. Sustainability.

\section{RESUMO}

Fatores internos e externos podem influenciar a implementação de ecoinovação nas empresas. Este artigo tem como objetivo analisar o que leva uma empresa química de um país emergente a adotar uma ecoinovação. Por meio de um estudo de caso qualitativo, com base nos fatores externos e internos, observou-se que a empresa é focada principalmente em Pesquisa e Desenvolvimento (P\&D) e inovação de produto, enfatizando que inovação pode trazer vantagens na integração da ecoinovação em seus processos. Em relação aos direcionadores para adoção da ecoinovação, a influência é mais externa, pelas pressões normativas, cooperação e tecnologia. O principal desafio é alinhar sustentabilidade à estratégia da empresa. A inovação é transversalmente integrada nos departamentos, mas isso não impulsionou estratégias de ecoinovação. Pesquisas sobre antecedentes da ecoinovação podem ajudar os formuladores de políticas a orientar e prever o comportamento das empresas e desenvolver mecanismos para estimular uma gestão ambiental.

Palavras-chave: Ecoinovação. Indústria Química. Sustentabilidade. 


\section{INTRODUCTION}

Companies are under pressure to apply sustainable development (SD) in its organizational practices, what turns latent the need for a reassessment of innovation and technological change (SMITH; VOß; GRIN, 2010). Innovation represents a relevant factor behind sustainability, stimulated by the advent of sustainable thinking that tries to integrate the economy and the environment (MAZZANTI, 2018). In this sense, innovations with reduced negative impacts on the environment, called eco-innovations (BITENCOURT et al., 2020) are crucial to create synergies between sustainability and competitiveness towards a green economy (MAZZANTI, 2018).

Under these circumstances, Boons and Lüdeke-Freund (2013) refer to eco-innovation studies as the search of new technologies and new social practices that make society more sustainable. Horbach, Rammer and Rennings (2012, p. 119) define eco-innovation: "Innovations leading to a noticeable reduction in environmental burdens. Positive environmental effects can be explicit goals or side-effects of innovations. They can occur within the respective companies or through customer use of products or services." Froehlich, Mello and Engelman (2017) synthesize that eco-innovations represent new or improved processes, new organizational forms, as well as new products or technologies that are beneficial to the environment.

Although there are barriers to overcome, many companies invest in successful eco-innovation and is considered as a key tool towards sustainable development (CHASSAGNON; HANED, 2015). Understand what are the motivations for the adoption of eco-innovation is extremely important to help policy makers at guiding and predicting companies' behavior and develop accurate mechanisms to prompt a more environmental management. In addition, for businesses, it is important to clarify what are the main factors that deserve its attention to expand strategies on sustainability and on innovation.

A company, to be considered sustainable, must integrate sustainability in its main abilities, skills and capabilities in most areas, such as corporate strategy, governance and stakeholders, clients and products, human resources and financial results (PARASCHI et al., 2012). Demirel and Kesidou (2011) analyzed determinants for different eco-innovations, from incremental innovation, with less impact to higher impact as integrated technologies, cleaner production, environmental research and development (R\&D).

One driver that has been stood out is the essential role played by top managers as key player for adoption of eco-innovation, acting as a trigger for the introduction of relevant environmental management practices (AZZONE; NOCl, 1998). Horbach (2008) also highlights its importance, and Weng and Lin (2011), in the same way, emphasize the influence from quality of human resources, organizational and government support and demand and regulatory pressures. 
Having an environmental management system (EMS) can positively influence the adoption of eco-innovation, depending on the maturity level of this system. Another important determinant for ecoinnovation is the participation of other areas within the company, with strong emphasis on the R\&D area. The learning process can be important for product innovation and implementation of an EMS (RENNINGS et al., 2006).

Stricter regulations tend to lead to the adoption of more eco-innovations (CHASSAGNON; HANED, 2015), but this is not always true. In emerging and developing countries with less stringent regulations, leading companies tend to invest in eco-innovations for other reasons than only to comply with regulations (DING; JIANMU, 2015).

A central argument in this research is that there are certain determinants (drivers) both internal and external to companies that influence the adoption of eco-innovation. These drivers have been identified and assembled in Bossle et al. (2016) in a systematic review of literature. In that sense, studying what drives companies in emerging countries to adopt eco-innovation and what is the influence of leadership innovation in the adoption of sustainable practices should be further explored. Within this context, by expanding the analysis in Bossle et al. (2016), the research problem proposed in this study is presented. The aim of this study is to analyze the influent drivers for adoption of the eco-innovation in a company from the chemical industry in an emerging country.

Choosing the chemical industry to analyze eco-innovation is justified by its high impact in the environment. The Environmental risk factors in the chemical industry are those related to the following agents: physical (heat, noise, ionizing and non-ionizing, vibration, and luminance) and chemicals and biological (virus, bacteria, fungus, etc.). In addition, it is worth to highlight that all chemical substances may cause damage to the environment when concentrations is above acceptable levels. Special attention should be given to POPs (persistent organic pollutants) that are persistent, i.e., slow to decompose, are volatile and therefore are distributed around the globe. Damage can occur both in the human population, and in animals, plants and even the assets. This damage can range from minor injuries to death and extinction of animal and plant species (FREITAS, 2000).

In this context, eco-innovation is a concept that simultaneously generate economic benefits and favors the protection and conservation of the environment mitigating the environmental risks of chemicals.

\section{THEORETICAL FOUNDATION}

Sustainable development also means to put together growing concerns with environment and socioeconomic issues (HOPWOOD; MELLOR; O'BRIEN, 2005). Economics must be a function of society and 
environment, not the other way around. Thus, sustainable should be based on the relationship between environment and society, with feedbacks' cycles for both sides, in which social and environmental equality are fundamental ideals (HOPWOOD; MELLOR; O'BRIEN, 2005).

Due to an increasing level of public concern and environmental regulations, companies are raising awareness with socio-environmental issues (BANERJEE, 2003). That is, regulatory pressures (macro level) influence public opinion, what ends up shaping companies behaviour (micro level). Sustainable development requires an economic and social progressive transformation (WCED, 1987). Considering this, sustainable development must be a continuous process of change, which may be related to system innovations that require an integrated redesign of products, lifestyle, process and structure. In that sense, Wals and Schwarzin (2012) worries include finding a way to include people, organizations and communities in these transitions, while recognising all benefits of doing things in a more sustainable way.

During 1990s two great movements took emphasis on sustainable development discussions, one concerned with how to measure sustainable development, and the other with economic growth boundaries towards sustainable development (ROBINSON, 2004). Therefore, there is an attempt to close this gap between ideas and practical/applicable issues, to turn the theoretical concept into pro-sustainable development actions, grounded on environmental, economic and social pillar. Nevertheless, this is a great challenge since our society and companies are, traditionally driven by the economic pillar.

In that sense, Iyer-Raniga and Treloar (2000) stress some important issues about sustainable development: a) interdisciplinary approach, needed due to the complex nature of the subject; b) environmental damages can be caused by slow changes, so it is necessary to be aware and attentive to these changes, since its outcome and effects can be drastic and devastating; and c) natural and social environment, in constant change and interrelated. In that way, sustainable development is a constructive process of a given goal, and not a state, that is, it is necessary to follow a long way towards (IYER-RANINGA; TRELOAR, 2000).

Banerjee (2003) identified different levels of strategical focus in companies when investigating entrepreneurs' perception of sustainable actions undertaken in their companies. Some companies seem to integrate environmental issues in higher levels of strategy than others. Top managers recognize the importance on acknowledge their companies' impact on the environment, and the urgent need for mitigating theses effects. They agree that is necessary to be sensitive to environmental problems and to take into account external stakeholders, undertaking action for the local community and being good corporate citizens. So, although their actions usually aim at economic benefits, they recognize their responsibility. The environmental orientation seems to reflect managers' awareness about environmental 
issues related to their companies and their responsibility (responsiveness) towards external stakeholders (BANERJEE, 2003).

Considering that society, companies and governments' needs are dynamic and the process of change proposed by sustainable development concept is continuous, emerges the need for approaching the innovation concept. Leadership in innovation can elucidate why some companies can improve industrial and environmental performance easily, as they are better able to respond to the dynamics of the competitive environment, taking advantage of new opportunities for innovation (CHASSAGNON; HANED, 2015).

In addition to the importance of including environmental concepts in corporate strategy, the environmental awareness of consumers is also a relevant variable for the production and consumption of sustainable products (HORBACH, 2008). Successful companies include environmental and social management as a central part of its strategic plan and integrate these issues in innovation practices (CHANG; CHEN, 2013).

Sustainability requires several changes and innovations, not only within the company, but generally for society. Technological change towards more sustainable systems is linked to structural and cultural changes, requiring some important transformations and transitions (ELZEN; WIECZOREK, 2005; SMITH; VOß; GRIN, 2010).

Bringing together innovation and sustainability comes the eco-innovation, which includes innovation as a contribution to the advancement of sustainability (FERNANDO; JABBOUR; WAH, 2019). Eco-innovation is essential in guiding companies towards sustainable development (LEE; WU; TSENG, 2018), since it is seen as multi and interdisciplinary approaches, that is, which encompasses activities of production, assimilation or exploitation of a product, production process, service or management or business method that is novel to the organization and which results in a reduction of environmental risk, pollution and other negative impacts to relevant alternatives (KEMP; PEARSON, 2008).

Eco-innovation is still a recent topic and has been discussed in the literature, both in relation to its definition (CARRILLO-HERMOSILLA; DEL RÍO; KÖNNÖLÄ, 2010; BOSSLE; BARCELLOS; VIEIRA, 2015; DEL RÍO; PEÑASCO; ROMERO-JORDÁN, 2016), and in relation to the need of having a specific theoretical framework for their study (DEL RÍO; PEÑASCO; ROMERO-JORDÁN, 2016). Being successful in the market is essential to socio-environmentally friendly products contribute to a transition towards sustainable development (DANGELICO, 2015; PUJARI, 2006).

Eco-innovation implies environmental improvements, while providing additional value for organizations, developing new business niches and better competitive behavior (ARRANZ; ARROYABE; FERNANDEZ DE ARROYABE, 2019). 
Because eco-innovation has particular characteristics, different drivers must be included in their strategies (JOVÉ-LLOPIS; SEGARRA-BLASCO, 2018). In this sense, former papers address environmental innovation as an "action to comply with the law and other regulations" (AZZONE; NOCI, 1998; GREEN; MCMEEKIN; IRWIN, 1994). Although regulation keeps its main role in the adoption of eco-innovation, other drivers that influence the adoption have been incorporated in the studies about companies' motivation (CHASSAGNON; HANED, 2015). It depends not only on internal factors, but also on external pressures (CAl; $\mathrm{LI}, 2018$ ), and these should be investigated to identify whether they are relevant in different contexts, e.g. emerging and developed countries and among different industries (CAl; LI, 2018). At this point, Bitencourt et al. (2020) in his meta-analytical study found that in countries that promote greater sustainable competitiveness by natural, social and intellectual capital, resource management and governance efficiency, they perform better in eco-innovative practices.

Specifically in a Latin American context, the concept of eco-innovation has been the subject of debates not only among researchers, but also in the process of formulating public policies, as found by Graf (2015) who analyzed innovation plans in three countries: Argentina, Brazil and Mexico focusing on the link between ecology, innovation and renewable energies.

Considering the importance of studying drivers for adoption of eco-innovation, both strategically to the company to increase its environmental performance and to policy-makers to implement mechanisms to stimulate eco-innovation (DEL RÍO; PEÑASCO; ROMERO-JORDÁN, 2016), Bossle et al. (2016) proposed a theoretical framework with the main drivers from the literature to be empirically investigated. According to the framework, external factors and internal factors can influence the adoption of eco-innovation by the companies, and increase its environmental performance and also postulate that the pressure from external drivers can push changes internally, pushing the company to act more environmentally friendly (BOSSLE et al., 2016).

Based on this framework, external factors cover regulatory pressures, government support, regulatory pressures, cooperation and environmental technology. Regulatory pressures relate to environmental regulation and concerns (CHASSAGNON; HANED, 2015), being typically exercised by the government (CAl; $\mathrm{LI}, 2018)$. So, companies that can exceed minimum compliance with environmental regulations can take advantage of pioneering innovation (CAl; LI, 2018; CHASSAGNON; HANED, 2015).

In this context, governments can act by driving eco-innovations by developing a supportive infrastructure, regulations, and incentives that encourage the adoption of green activities (FERNANDO; JABBOUR; WAH, 2019; DORAN; RYAN, 2012).

Normative pressures, in turn, concern the pressures exerted by its stakeholders, such as customers and suppliers (CAl; LI, 2018). Cooperation, on the other hand, appears to be an important driver, since 
eco-innovations require more external knowledge than traditional innovations, and for this reason, organizations seek in cooperation to access external sources of information (HOJNIK; RUZZIER, 2016).

Finally, Fernando and Wah (2017) argue that the implementation of technologies is fundamental for eco-innovation, because, according to the authors, the development of new technologies requires investments in research and development, which consequently induce additional innovations.

At the same time, internal factors derived from assets within a company also determine the choice of eco-innovations, including efficiency, environmental capability, and environmental management concerns, including environmental leadership, human resource quality, and environmental strategy, including company culture. Efficiency is reported as a driver for eco-innovations, as it is linked to factors such as cost reduction, motivations to update equipment, investments in R\&D and EMS Systems (Organizational Capacity) (BOSSLE et al., 2016). Environmental capacity refers to a company's ability to adopt ecoinnovative responses, integrating, coordinating, building and reconfiguring their skills and resources for appropriate environmental practices (CAl; ZHOU, 2014; BOSSLE et al., 2016).

In addition, Arranz et al. (2020) demonstrated that there is a parallel between the knowledge and skills necessary for the development of eco-innovation and innovation, highlighting the interrelationship between the two processes, which makes companies that have already developed innovations more likely to develop eco-innovations.

Associated with this, there is evidence in the literature that the environmental managerial concern, that is, the concern of managers regarding environmental issues, is also an important issue. So, the support of top executives drives the adoption of eco-innovation (EIADAT, 2008). Therefore, it is necessary to have environmental leadership, that is, a leader who is able to influence other individuals in favor of environmental practices (BOSSLE et al., 2016). Also relevant is the quality of human resources, as well as the adoption of strategies that signal the commitment of the organization to the environment, including in its culture behaviors and processes that denote this concern (BOSSLE et al., 2016).

Given the above, this study aims at investigating the influence of those drivers in a company from the chemical industry, including the influence of innovation on the adoption of eco-innovation (see Figure 1). Companies and innovation process are path dependent, what can a priori turn companies that were innovative in the past to be considered as potential innovators in the present (HORBACH, 2008). According to Tsai and Liao (2017), the influence of innovation on eco-innovation varies according to the level of customer's demand for environmental products, environmental awareness of markets, regulations and government support.

What "new" or "newness" is dependent on the context where the company or the market takes place (CARRILLO-HERMOSILLA; DEL RÍO; KÖNNÖLÄ, 2010), and innovation strategies bear to increasingly 


\section{Gestãoe \\ Desenvolvimento}

e-ISSN: 2446-6875

p-ISSN: $1807-5436$

comprise environmental features with different intensities and rates (FRONDEL; HORBACH; RENNINGS, 2007). Nevertheless, while innovation leadership can be a driver for adoption of eco-innovation (CHASSAGNON; HANED, 2015), innovation process can also be refrained by path dependency, what can turn certain aspects of innovation dependent on a given industry, company or technological field (PAVITT, 2005).

Firms need to innovate, so, in response to demands and consumer's lifestyles changes, and to take advantage of the opportunities offered by technology and markets, structures and dynamics also changes. Maybe this is an important point that eco-innovation concept now encompasses and that makes it a special type of innovation. Not all innovations are eco-innovations, but all eco-innovations are innovations, with some important features that set them apart.

Figure 1 - Framework for analyzing the influence of innovation and other drivers for adoption of eco-innovation

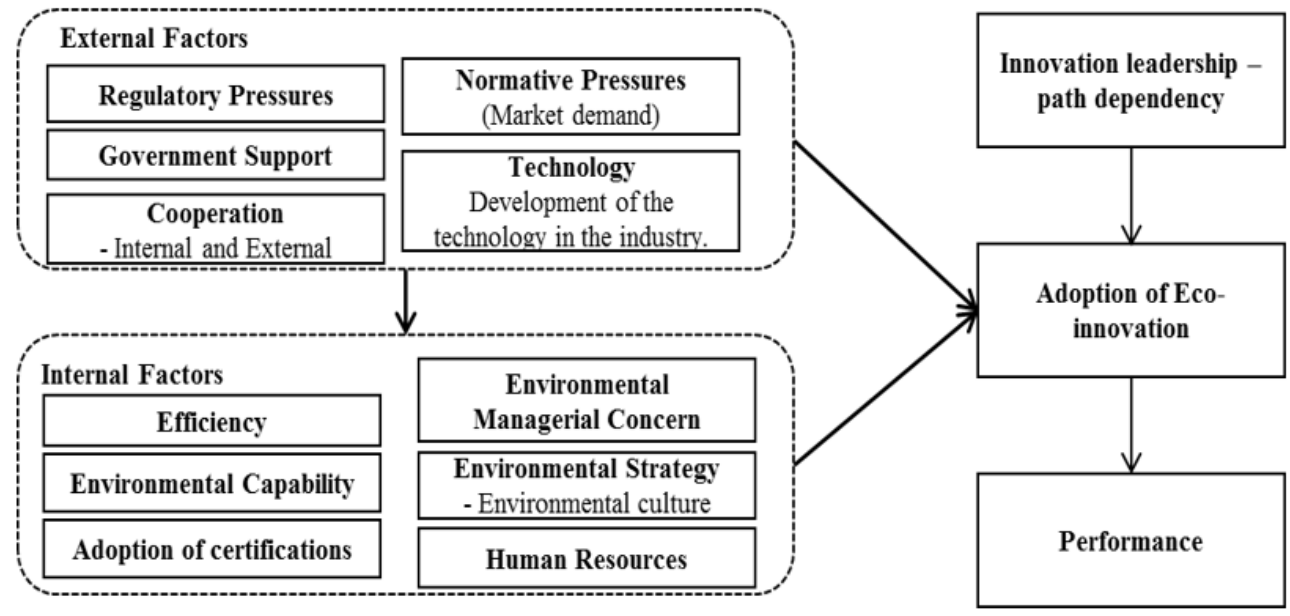

Source: Adapted from Bossle, Barcellos and Vieira (2015).

\section{METHODOLOGY}

A qualitative case study was employed for this research. This approach is justified due to the need to refine an existing theory, which allows new relationships to be investigated and reveals complex processes, in this way illustrating the influence of social context (SHAH; CORLEY, 2006).

An attempt was made to identify a representative company that met the following criteria: a) recognized in the market for its innovative capacity; b) innovation must be a deliberate organizational strategy; c) the enterprise should embody an innovation-oriented culture (innovation should be part of the mission, vision and organizational values of the enterprise). The company selected stands out from 


\section{Gestãoe \\ Desenvolvimento}

e-ISSN: 2446-6875

p-ISSN: $1807-5436$

the competition because a) it is widely recognized in the different segments it operates; b) innovation is part of its mission and values; c) it produces product and process patents; d) innovation is part of its social reporting.

To guide data collection, a protocol was developed which is a strategy recommended by Yin (2005), which was built from the categories identified in the theoretical framework: (1) External factors: regulatory pressures, government support, cooperation, normative pressures, technology ; (2) Internal factors: efficiency, environmental capability, adoption of certifications, environmental managerial concern, environmental strategy, human resources. After the construction of the protocol, a semi-structured interview script was developed, the questions sought to investigate how each of these categories occurred in the target company of the study. The interview script was validated by a researcher professor specialized in the subject.

The semi-structured and in-depth interviews were conducted with different levels and areas, indicated by the company. Thus, the choice criterion adopted was related to the leaders at the strategic level. Data on the different areas represented by the managers was validated using triangulation. All interviews were recorded with the consent of the participants and then transcribed for analysis so that any doubts could be clarified and potential misinterpretations eliminated. This contributes to ensuring the integrity and reliability of the analysis of the data collected.

To protect the identity of the participants, they were randomly assigned a sequential identifier (Participant 1 - E1, Participant 2 - E2 and so on). Table 1 summarizes the participants' profiles. 
Table 1 - Participants' profiles

\begin{tabular}{|c|c|c|}
\hline Job/position & $\begin{array}{l}\text { Time with the } \\
\text { company }\end{array}$ & Education \\
\hline (E1) Technology Manager & $13 \mathrm{mo}$ & $\begin{array}{l}\text { Chemistry technician. BSc Chemistry. MSc Organic Chemistry. PhD } \\
\text { Materials Engineering. }\end{array}$ \\
\hline $\begin{array}{l}\text { (E2) Technology Projects } \\
\text { Coordinator }\end{array}$ & 7 yrs & $\begin{array}{l}\text { Chemistry technician. BSc Chemistry. MBA Business and Project } \\
\text { Management. }\end{array}$ \\
\hline $\begin{array}{l}\text { (E3) Occupational Health, } \\
\text { Safety and Environment } \\
\text { Coordinator }\end{array}$ & 3 yrs & $\begin{array}{l}\text { Chemistry technician. BSc Environmental Engineering. BSc OSH. } \\
\text { International MBA Environmental Management. }\end{array}$ \\
\hline $\begin{array}{l}\text { (E4) Management and } \\
\text { innovation Analyst }\end{array}$ & 5 yrs & Chemistry technician. BSc Production Engineering (in progress). \\
\hline $\begin{array}{l}\text { (E5) Planning and New } \\
\text { Businesses Manager }\end{array}$ & 17 yrs & BSc Commercial Engineering. \\
\hline $\begin{array}{l}\text { (E6) Coordinator of the } \\
\text { Francisco Xavier Kunst } \\
\text { Foundation }\end{array}$ & 3 yrs & BA Social Science. Specialist, HR Planning and Management. MA Education. \\
\hline (E7) Environmental Analyst & $2 \frac{1}{2}$ yrs & Chemical Engineering. \\
\hline $\begin{array}{l}\text { (E8) Internal and Institutional } \\
\text { Marketing Coordinator }\end{array}$ & $1 \mathrm{yr}$ & Journalism. \\
\hline $\begin{array}{l}\text { (E9) Development } \\
\text { Consultant }\end{array}$ & 6 yrs & BA Business. MBA Strategy and Innovation. \\
\hline $\begin{array}{l}\text { (E10) Organizational } \\
\text { Development Director }\end{array}$ & 3 yrs & BSc Accounting. MBA Business Management. MBA Social Technology. \\
\hline
\end{tabular}

\section{Source: developed by the authors.}

The total number of interviews (10) fulfilled the saturation criteria, i.e. the repetition of the data collected indicated that further interviews were not required. An additional methodological precaution was the triangulation of data, which in this study was based on the different managerial areas and positions of the participants and on the different data collection formats used (interviews and documentary analysis).

Secondary data were obtained from documents supplied by the company. Overall, documentary information is relevant in case study approaches (YIN, 2005), as the main purpose of information obtained from documents is to strengthen and support other sources of evidence, particularly to supply details. The following company's documents were examined: a) the company's social report; b) commemorative book of company's anniversary; c) company's portal; d) environmental management system handbook; e) articles printed in the company's monthly newsletter. 
All data collected were processed using qualitative content analysis, a method by which the key elements are broken down into categories that match the theoretical framework adopted. Categorization is identified by Selltiz, Jahoda and Cook (1965) as an effective technique for data organization and reduction as the information is grouped into a limited number of categories. The following categories were used in this study: (1) External factors: regulatory pressures, government support, cooperation, normative pressures, technology; (2) Internal factors: efficiency, environmental capability, adoption of certifications, environmental managerial concern, environmental strategy, human resources.

These categories were created following the recommendations of Bardin (2010), by which elements are first isolated and then grouped together according to the following characteristics: (a) mutually exclusive, i.e. each element belongs to a single category; (b) homogeneity: the mutually exclusive principle depends of the homogeneity of the categories, so a single criterion should be used to determine how the category is organized; (c) pertinence: a category is considered pertinent when it is adapted to the material of analysis selected and when it belongs to the selected theoretical framework, i.e. it is suitable to the research aim; (d) objectivity and reliability, i.e. the categories should be clearly defined to eliminate any doubts concerning the allocation of elements; (e) productivity: a set of categories is productive is it provides elements that are rich in inference indexes, new assumptions and concrete data.

\section{RESULTS AND ANALYSIS}

Results are discussed in this section, mainly based on the perceptions of different employees from the studied company and secondary data (social reports, websites and other reports).

Although the company states that sustainability is one of its main core values, as could be seen in the interviews, including sustainability in the strategy and integrating it in all departments within the company is still a challenge. The company mainly eco-innovates in products, both in terms of reducing impact on the environment and in reducing risks for workers who will handle with the adhesives they produce.

\subsection{SUSTAINABILITY}

The decision for adopting sustainability (and eco-innovation) is linked to a long-term vision, in which they must predict impacts and needs from the environment and plan its strategy, products, location of plants, etc. (E3). The company is also concerned with social issues and wellbeing of employees, that should feel happy while at work (E3). These social concerns are also related to the safety of the workers who will manipulate their products and should be protected from harmful products (E5). 


\section{Gestãoe \\ Desenvolvimento}

e-ISSN: 2446-6875

p-ISSN: 1807-5436

The main drivers for investing in sustainability are related to growth and long-term vision of business, environment protection and improvement of stakeholders' wellbeing. Suppliers are also evaluated in terms of compliance with environmental law and in relation to sustainability (E7). E10 highlights three aspects of sustainability that are included in the company's practices:

a) Adoption of environmental management system, ISO 14001, internal awareness campaigns, and development of human resources' practices; b) Having a stablished Foundation with social projects and activities for the community; c) Applying sustainability principles in products, such as the use of ecological fibers, alternative materials for solvent in the adhesive, etc. (E10).

Although the company does not apply specific indicators for assessing sustainability, environmental, social and even cultural (as a 4th pillar of sustainability) precepts are taken into account when developing a new product, mainly when it is related to a radical innovation. Payoff (economic aspect) is crucial for the final decision, but social issues related to internal factors, such as workers' wellbeing are considered, as well as environmental efficiency through a better use of resources.

The company is very well developed in terms of innovation, with 29 patents and 28 innovation awards only in 2012. According to the results from interviews, the company developed an innovation culture that permeates all departments through an integrative and professional management (E1 and E2). Nevertheless, its family management origin, turn this process much more top-down, being a response from the board of directors' (management board) guidance (E1). This strong focus in innovation started as a strategy in 1997 when the company developed its first strategic plan, building up four strategic guidelines, incorporating innovation and internationalization. The company has developed a strong culture of innovation and incorporating a new campaign, claiming that innovation and internationalization belongs to company's DNA (E5). Sustainability is much more recent, the company has started to include this as a value around 2011. Next, the main drivers for adoption of eco-innovation are analyzed.

\subsection{EXTERNAL DRIVERS}

\subsubsection{Regulation}

Regarding regulation, it was pointed out in the interviews that the company belongs to the chemical industry, considered with a high environmental impact, regulations are already very strict. At this point, Wagner and Llerena (2011), when comparing different sectors of the industry, found that, with respect to eco-innovation, there can be great variation among the sectoral contexts. Even though, the interviewees 
affirm in the company studied the environmental actions go beyond mere compliance with legislation (E3). Considering its accentuated focus in innovation, the company tries to anticipate market and regulatory trends, even though it is still seen that Brazilian market and regulation are not very demanding in that sense.

This result is confirmed by the literature that points to regulation as an important element for ecoinnovation (HORBACH; RAMMER; RENNINGS, 2012), where it can offer a competitive advantage in the face of pioneering (CHASSAGNON; HANED, 2015).

\subsubsection{Normative pressure}

Normative pressure is maybe one of the most relevant drivers for adoption of eco-innovation in this company. Normative pressure is related to legitimacy, when companies try to anticipate to the requirements from the market, or they observe other companies and try to behave according its institutional field (BOSSLE et al., 2016). Normative pressures is also related to market demand and demand from different stakeholders (CAl; LI, 2018). Adopting eco-innovation was encouraged by pressure from banks and funding agencies, since sustainability is one of the issues they assess when a loan is needed. Funding will be provided accordingly, the more sustainable, more funding with more interesting interest (E3).

\subsubsection{Governmental support}

The perception from interviews is that government support is still very incipient in Brazil, does not pushing companies to act more pro-actively towards sustainable development. E3 thinks that in Brazil should have more sustainable public policies to turn the whole society more sustainable. So, there is a need for the government to realize the importance of eco-innovative activities, since according to a study developed by Doran e Ryan (2012) eco-innovation in the European Union was responsible for stimulating economic growth and development, and this type of innovation is seen as a means to help countries recover from the financial crises (DORAN; RYAN, 2012).

\subsubsection{Cooperation}

The company considers cooperation as an important strategy to further develop innovation projects and new product development. They stablish networks and cooperative relationships not only with other companies, but also looking for resources from governmental research agencies, such as CNPq, SENAI and Finep. By doing this, the company raise awareness of the importance of collaborating with research agencies (E1). They also have important partnerships with universities, mainly from the region (southern Brazil), but also with other universities, to develop and to test new products (E1). There is also collaboration 


\section{Gestãoe \\ Desenvolvimento}

e-ISSN: 2446-6875

p-ISSN: $1807-5436$

with other companies, for example, to assess technical feasibility of a product, when a specific machine is required (E1).

Partnership and collaboration with other companies (clients and suppliers) is a strong driver for innovation. These partnerships are mainly due to technological agreement, when they need to use an equipment, for example, and go to the market to seek for a company that possesses the equipment, know how, knowledge, products (HOJNIK; RUZZIER, 2016).

\subsubsection{Technology}

Sustainability is highly correlated with product eco-innovation, it is not integrated in companies' strategy nor is it taken into account by all departments within the company. Research \& Development department is the department that is usually in charge of finding a renewable resource for using as a raw material, or reusing residual components from other industries or plants (E6 and E7). The problem of using residuals from other plants is the uncertainty in relation to the offer (E7), what can bring difficulties to keep using this kind of raw material. These results corroborate with the statements of Fernando and Wah (2017) who report that investments in research and development are drivers of eco-innovation.

The company was leader in Latin America in developing alternatives that could replace chemical solvents by water-based adhesive technologies, with less environmental impacts. Going further, they developed hot melts adhesives, and the powder adhesive, that is a breakthrough eco-innovation for the company (E1 and E7). Although they are investing in alternatives solvents still represent 36\% of sales, while hot melt is $31 \%$, water-based adhesives, $29 \%$, others $(3,7 \%)$, and powder only $0,3 \%$. According to E10, the powder has a more complex process, requiring from clients investments in new equipment and development of new process. To overcome these barriers, partnerships with large companies are under development to spread product insertion on the market (E10).

The concept of the powder adhesive was born internally, driven by research and development (R\&D) in 2006. At the time, our focus was the shoes sector, but we realized that to innovate, we should go beyond. The idea was born from the vision of a critical commercial and technical analysis for identifying business opportunities in the light of sustainability (E4).

Cooperation with other companies and with universities is boosted by the development of new technologies, at the same time that helped to push the company to increase investments in more ecoinnovative products. 
Research and tests with new raw materials in adhesives have been made even without the existence of a machine. The initial results were beyond expectations, but to innovate in an exclusively collage process unique it was necessary to start a technology partnership in 2008 to improve the bonding process using the powder adhesive (E5).

Other partnerships were developed in 2009 e 2010, with companies that would apply the powder adhesives. These phases of validation and test were successful and the process was approved by clients. "We did a partnership with a large shoe's company that produced around two million shoes using this new system for bonding shoes. So before launching in the market, we were already sure that the product works, and this helped commercially" (E5).

\subsection{INTERNAL DRIVERS}

\subsubsection{Environmental managerial concern}

Regarding top management support the results suggest that the main challenge for the company to increase sustainability and eco-innovation is to align these sustainable concepts with the company's vision (E10). That is to really integrate sustainability in the company's strategy. What was inferred from the interviews is that top managers and the executive committee are not very concerned with those issues and therefore, sustainable policies are not spread throughout the company. The managerial performance in the case analyzed contrasts the assumptions of the literature that points out the importance of the support of the main executives drives the adoption of eco-innovation (EIADAT, 2008).

It became clear that sustainability is directly associated with the development of sustainable products. Nevertheless, disseminating a culture focused on eco-innovation is still hard to be done by top managers in this company. The awareness for sustainability and dissemination of eco-innovation culture is presented in reports and in processes regarding to new product development, but not in the business model. A culture of innovation is widespread, but the culture that influence eco-innovation is not. It is necessary to improve the awareness of managers towards sustainability to align sustainability with the business model, and expand this culture of sustainability beyond the scope of products and processes.

Usually the start to produce and pay royalties for the companies they negotiate with (E5).

\subsubsection{Certifications}

Certifications and other quality programs are also important drivers to push the company to adopt eco-innovation (HOJNIK; RUZZIER, 2016). In the studied company, the adoption of the ISO 14001 certification was an example that pushes the company for a more sustainable management. In addition, 
it was developed in the company, an information software to integrate all demands required by different certifications, or ISOs. This integrated system, allows the management of all procedures required to comply with ISOs 9001 and 14001, as well as with a quality program that the company belongs to (PGQP), increasing efficiency and avoiding rework (E4). These programs also require the assessment of sustainable impact of some areas and departments.

\subsubsection{Environmental strategy and culture}

In terms of strategy, it was possible to observe from the data collected that, in the case studied, sustainability is still very incipient, with some one-off actions, being part of their values and management policy, but only as one of the values, not as a main core business. They are starting to introduce some projects, but it is not embedded in their strategy. It is maybe more a result of external pressure from suppliers, marketing, etc: "the company invests a lot in sustainability, but it is a disassociated from investment an investment plan" (E3). "We do not have explicitly in the strategic plan anything about sustainability, we work to create value, not only for economic aspects" (E4).

Even if social reports have been published since 2006 (only available online from 2009), with approaches such as eco-efficiency and environmental impact, environmental issues are not embedded in companies' culture.

\subsubsection{Human resources}

As for human resources, it can be verified that in the company studied, in 2010, with new guidelines in the strategic plan to create and consolidate "high performance teams", it was created what is called University Company, with training programs coordinated by organizational development area. The aim of these programs is to promote excellence in management and innovation through valuing people, development of systemic thinking, strategic leadership, long-term vision and generation of value.

Employees are incentivizing to provide ideas to increase efficiency through an institutionalized program (E4). Most of the ideas, around $60-70 \%$ are related to process improvements. They receive around 500 ideas every year, and employees receive rewards according to the amount and quality of their ideas. These results confirm statements in the literature that point out qualified human resources as antecedents of eco-innovation (BOSSLE et al., 2016).

\subsubsection{Performance}

Environmental goals are assessed since 2010 and are related to increasing efficiency through better use of resources: "Water and energy savings, reducing the generation of hazardous waste, increasing 
treatment of effluents and reducing emissions. When the established goals are not met, an action plan is drew up. Usually, it comes from assessment of ISO 14001's management" (E7).

\section{DISCUSSION}

From the analysis presented some perceptions were evidenced, it is clear that the chemical company analyzed in this study is very strong in its innovation capacity, what might have influenced the adoption of sustainable practices, but these practices are still under development. This suggests that the knowledge required for eco-innovations is more complex and uncertain than for the adoption of traditional innovations (KETATA; SOFKA; GRIMPE, 2015). Besides that, for this type of innovation the environmental, economic and social dimensions must be connected, thus requiring a socio-environmental management approach to be employed (OLIVEIRA; IPIRANGA, 2009).

It is evidenced by the results, eco-innovation was identified in some specific products, but it is not included in the company strategy and culture, nor is it integrated throughout all areas within the company, even if they are implementing. Surprisingly the company states in its reports that they develop ecoinnovation, but none of the interviewees supported this as a core value.

Although the regulation is a facilitator for the adoption of eco-innovations, in the company studied, this point seems not to be the main motivator, since this search adopts a position of pioneering in its sector. Such involvement can ensure a competitive advantage vis-à-vis competitors (CAl; LI, 2018; CHASSAGNON; HANED, 2015). It is also apparent that, although not linked to its main strategy, some environmentally sustainable initiatives have been adopted. At this point, it is noted that these are mainly due to external influences.

It is evidenced by the results that sustainability is very incipient for this company, mainly focused in research and development, and concentrated in the main product developed, the adhesive powder. Therefore, being an innovative company can bring some advantages to start to integrate eco-innovation in its processes, but it is not determinant. The process of developing the adhesive powder was influenced by the willingness of acquiring competitive advantage in relation to its competitors, acting as a first mover to assure economic profitability and market share. This product is not as (economic) profitable as the others but being more sustainable can guarantee new markets' niches.

At this point, Lazzarotti et al. (2014) in their case study at a pulp company found that from an immediate view environmental investment may not be as attractive. Investments only started to show returns in the medium and long term, thus generating higher financial performance over the years. 
At the same time, Fernando, Jabbour and Wah (2019) argue that many companies focused on green technology concentrate mainly on product creation, neglecting other dimensions of innovation, such as service innovation for example. From the study developed by the authors with Malaysian companies it can be verified that the innovation capacity of services acted as a mediator in improving the transition from eco-innovation to sustainable business performance. Thus, increasingly manufacturing firms are not only focusing on the development of new products, but also seeking to understand the servitization as a core function and incorporating it in their business models.

In addition to the long-term strategy to include sustainability as a goal, the introduction of sustainable products and processes is due to the company's willingness to protect workers' health and wellbeing, considering the injuries that chemical products can cause during its manipulation, as highlighted in Freitas (2000). The main challenge for the company to increase sustainability and eco-innovation is to align sustainable concepts with the company's vision. In relation to the drivers for adoption of eco-innovation, the influence is more external, from normative pressures, cooperation and technology. Another interesting issue is the relationship between cooperation and technology, since the development of new technologies and products by the company influenced the enhancement of collaboration with other companies and universities.

The investigation on what is behind the adoption of eco-innovation can help policy makers at guiding and predicting companies' behavior and develop accurate mechanisms to prompt a more environmental management. A company, to be considered sustainable, must integrate sustainability in its main abilities, skills and capabilities in most areas, such as corporate strategy, governance and stakeholders, clients and products, human resources and financial results (PARASCHIV et al., 2012).

Although the company has integrated innovation transversally throughout all departments, this has not pushed eco-innovation strategies. The fact of being a family business in the origin and the topdown decisions structure are more determinant and this environmental aspect has apparently not been incorporated. This result is in consonance with Dangelico (2017), whose study indicated that family firms are better than non-family firms to increase innovation in their businesses, both in terms of firm capability and by product differentiation. Nevertheless, as indicated by Dangelico (2017), further research is needed to understand drivers for adoption of eco-innovation by family businesses.

Besides that, although the importance of the role of managers in the impact of eco-innovation activities was evidenced in the literature, this dominant role was not found in the studied company. Such positioning can have disadvantages in relation to the company's orientation towards sustainable actions. Since the manager's inclination to incorporate sustainability aspects into business is seen as a key factor 


\section{Gestãoe \\ Desenvolvimento}

e-ISSN: 2446-6875

p-ISSN: 1807-5436

that will differentiate truly sustainable and innovative innovators with attention to environmental and/or social aspects (KETATA; SOFKA; GRIMPE, 2015).

\section{FINAL CONSIDERATION}

This article aimed to analyze what leads a chemical company from an emerging country to adopt eco-innovation. Thus, the external and internal factors that may influence the adoption of eco-innovation were analyzed. It was found that the company is mainly focused on Research and Development (R\&D) and product innovation, emphasizing that innovation can bring advantages in the integration of eco-innovation in its processes. Regarding the drivers for adopting eco-innovation, the influence is more external, due to normative pressures, cooperation and technology.

The results show that the main challenge faced by the studied company is to align eco-innovation with the company's strategy. Although it has been identified that innovation is integrated into departments, this fact has not driven eco-innovation strategies. These findings have implications for policymakers. Research on the background of eco-innovation can help policy makers to guide and predict the behavior of companies and develop mechanisms to encourage more environmental management.

Finally, the results of this study provide insight into the points that must be investigated within the organization to shape its capacity for eco-innovation, since understanding the mechanisms before it enables more efficient and effective actions to be taken. Given the importance of this topic and considering the infancy of the studies in this field, it is expected that further research will be carried out under this scope, especially with regard to longitudinal studies since the decision to adopt eco-innovations is linked to a long-term vision.

However, some limitations of this study must be noted. It is recognized that the case of this study was selected based on the reasons of adequacy and not of representativeness, so it cannot be guaranteed the generalization of the findings. Future research is needed to include more samples with idiosyncratic characteristics to allow more comprehensive assumptions about innovative features that affect ecoinnovation.

\section{ACKNOWLEDGEMENT}

"This study was financed in part by the Coordenação de Aperfeiçoamento de Pessoal de Nível Superior - Brasil (CAPES) - Finance Code 001" 


\section{Gestãoe \\ Desenvolvimento}

e-ISSN: 2446-6875

p-ISSN: 1807-5436

\section{REFERENCES}

ARRANZ, N.; ARROYABE, M.; LI, J.; ARROYABE, J. Innovation as a driver of eco-innovation in the firm: An approach from the dynamic capabilities theory. Business Strategy and the Environment, Jan. 2020.

ARRANZ, N.; F. ARROYABE, C.; FERNANDEZ DE ARROYABE, J. C. The effect of regional factors in the development of eco-innovations in the firm. Business Strategy and the Environment, v. 28, n. 7, p. 1406$1415,2019$.

AZZONE, G.; NOCl, G. Seeing ecology and "green" innovations as a source of change. Journal of Organizational Change Management, v. 11, n. 2, p. 94-111, 1998.

BANERJEE, S. B. Who sustains whose development? Sustainable development and the reinvention of nature. Organization Studies, v. 24, n. 1, p. 143-180, 2003.

BARDIN, L. Análise de Conteúdo. Lisboa: Edições 70, 2010.

BITENCOURT, C. C.; SANTINI, F. O.; ZANANDREA, G.; FROEHLICH, C.; LADEIRA, W. J. Empirical generalizations in eco-innovation: A meta-analytic approach. Journal of Cleaner Production, v. 245, p. 118721, 2020

BOONS, F.; LÜDEKE-FREUND, F. Business models for sustainable innovation: state-of-the-art and steps towards a research agenda. Journal of Cleaner production, v. 45, p. 9-19, 2013.

BOSSLE, M. B.; BARCELLOS, M. D.; VIEIRA, L. M.; SAUVÉE, L. The drivers for adoption of eco-innovation. Journal of Cleaner production, v. 113, p. 861-872, 2016.

BOSSLE, M. B.; DE BARCELLOS, M. D.; VIEIRA, L. M. Eco-innovative food in Brazil: perceptions from producers and consumers. Agricultural and Food Economics, v. 3, n. 1, p. 1-8, 2015.

CAI, W.; LI, G. The drivers of eco-innovation and its impact on performance: Evidence from China. Journal of Cleaner Production, v. 176, p. 110-118, 2018.

CARRILLO-HERMOSILLA, J.; DEL RÍO, P.; KÖNNÖLÄ, T. Diversity of eco-innovations: Reflections from selected case studies. Journal of cleaner production, v. 18, n. 10-11, p. 1073-1083, 2010.

CHANG, C. H.; CHEN, Y. S. Green organizational identity and green innovation. Management Decision, v. 51, n. 5, p. 1056-1070, 2013. 


\section{Gestãoe \\ Desenvolvimento}

e-ISSN: 2446-6875

p-ISSN: $1807-5436$

CHASSAGNON, V.; HANED, N. The relevance of innovation leadership for environmental benefits: A firm-level empirical analysis on French firms. Technological Forecasting and social change, v. 91, p. $194-207,2015$

DANGELICO, R. M. Green product innovation: where we are and where we are going. Business Strategy and the Environment, v. 25, n. 8, p. 560-576, 2016.

DANGELICO, R. M. What drives green product development and how do different antecedents affect market performance? A survey of Italian companies with eco-labels. Business Strategy and the Environment, v. 26, n. 8, p. 1144-1161, 2017.

DEL RÍO, P.; PEÑASCO, C.; ROMERO-JORDÁN, D. What drives eco-innovators? A critical review of the empirical literature based on econometric methods. Journal of Cleaner Production, v. 112, p. 21582170, 2016.

DEMIREL, P.; KESIDOU, E. Stimulating different types of eco-innovation in the UK: Government policies and firm motivations. Ecological Economics, v. 70, n. 8, p. 1546-1557, 2011.

DING, M.; JIANMU, Y. Eco-innovation determination based on structural equation modeling: identifying the mediation and moderation effect. Science and Business Administration, v. 16, 2015.

DORAN, J.; RYAN, G. Regulation and firm perception, eco-innovation and firm performance. European Journal of Innovation Management, v. 15, n. 4, p. 421-441, 2012.

EIADAT, Y.; KELLY, A.; ROCHE, F.; EYADAT, H. Green and competitive? An empirical test of the mediating role of environmental innovation strategy. Journal of World Business, v. 43, n. 2, p. 131-145, 2008.

ELZEN, B.; WIECZOREK, A. Transitions towards sustainability through system innovation. Technological forecasting and social change, v. 72, n. 6, p. 651-661, 2005.

FERNANDO, Y.; JABBOUR, C. J. C.; WAH, W. X. Pursuing green growth in technology firms through the connections between environmental innovation and sustainable business performance: Does service capability matter? Resources, Conservation and Recycling, v. 141, p. 8-20, 2019.

FERNANDO, Y.; WAH, W. X. The impact of eco-innovation drivers on environmental performance: Empirical results from the green technology sector in Malaysia. Sustainable Production and Consumption, v. 12, p. 27-43, 2017. 


\section{Gestãoe \\ Desenvolvimento}

e-ISSN: 2446-6875

p-ISSN: 1807-5436

FROEHLICH, C.; MELLO, D.; ENGELMAN, R. Inovação e sustentabilidade: um olhar sobre a produção científica publicada em eventos da Associação Nacional de Pós-Graduação e Pesquisa em Administração. Gestão e Desenvolvimento, v. 14, n. 2, p. 19-32, 2017.

FRONDEL, M.; HORBACH, J.; RENNINGS, K. End-of-pipe or cleaner production? An empirical comparison of environmental innovation decisions across OECD countries. Business strategy and the environment, v. 16, n. 8, p. 571-584, 2007.

GRAF, P. Eco-innovation-a new paradigm for Latin América? Gestão e Desenvolvimento, v. 12, n. 1, 2015.

GREEN, K.; MCMEEKIN, A.; IRWIN, A. Technological trajectories and R\&D for environmental innovation in UK firms. Futures, v. 26, n. 10, p. 1047-1059, 1994.

HOJNIK, J.; RUZZIER, M. What drives eco-innovation? A review of an emerging literature. Environmental Innovation and Societal Transitions, v. 19, p. 31-41, 2016.

HOPWOOD, B.; MELLOR, M.; O'BRIEN, G. Sustainable development: mapping different approaches. Sustainable development, v. 13, n. 1, p. 38-52, 2005.

HORBACH, J. Determinants of environmental innovation-New evidence from German panel data sources. Research policy, v. 37, n. 1, p. 163-173, 2008.

HORBACH, J.; RAMMER, C.; RENNINGS, K. Determinants of eco-innovations by type of environmental impact-The role of regulatory push/pull, technology push and market pull. Ecological economics, v. 78, p. 112-122, 2012.

IYER-RANIGA, U.; TRELOAR, G. A context for participation in sustainable development. Environmental management, v. 26, n. 4, p. 349-361, 2000.

JOVÉ-LLOPIS, E.; SEGARRA-BLASCO, A. Eco-innovation strategies: A panel data analysis of Spanish manufacturing firms. Business Strategy and the Environment, v. 27, n. 8, p. 1209-1220, 2018.

KEMP, R.; PEARSONN, P. (eds.). Final report of the project Measuring Eco-Innovation. Maastricht, 2008. Disponível em: http://www.merit.unu.edu/MEl/index.php.

KETATA, I.; SOFKA, W.; GRIMPE, C. The role of internal capabilities and firms' environment for sustainable innovation: evidence for G ermany. R\&d Management, v. 45, n. 1, p. 60-75, 2015. 


\section{Gestãoe \\ Desenvolvimento}

e-ISSN: 2446-6875

p-ISSN: $1807-5436$

LAZZAROTTI, F.; PAVÃO. Y. M. P.; SHENEM, S.; ALBERTON, A. Tecnologias ambientais e os impactos no desempenho econômico-financeiro: o caso da Celulose Irani S/A. Contextus - Revista Contemporânea de Economia e Gestão, v. 12, n. 1, 2014.

MAZZANTI, M. Eco-innovation and sustainability: dynamic trends, geography and policies. Journal of environmental planning and management, v. 61, n. 11, p. 1851-1860, 2018.

OLIVEIRA, L. G. L.; IPIRANGA, A. S. R. A inovação sustentável e a dinamização do sistema local do agronegócio do caju cearense. Contextus - Revista Contemporânea de Economia e Gestão, v. 7, n. 1, 2009.

PARASCHIV, D. M. et al. Eco-innovation, responsible leadership and organizational change for corporate sustainability. Amfiteatru Economic Journal, v. 14, n. 32, p. 404-419, 2012.

PAVITT, K. Innovation Processes. In: FAGERBERG; MOWERY; NELSON (Eds.). The Oxford Handbook of Innovation. Oxford: Oxford University Press, p. 86-114, 2005.

PUJARI, D. Eco-innovation and new product development: understanding the influences on market performance. Technovation, v. 26, n. 1, p. 76-85, 2006.

RENNINGS, K.; ANKELE, K.; ZIEGLER, A.; HOFFMANN, E. The influence of different characteristics of the EU environmental management and auditing scheme on technical environmental innovations and economic performance. Ecological Economics, v. 57, n. 1, p. 45-59, 2006.

ROBINSON, J. Squaring the circle? Some thoughts on the idea of sustainable development. Ecological Economics, v. 48, n. 4, p. 369-384, 2004.

SELLTIZ, C.; JAHODA, M.; COOK, S. W. Métodos de pesquisa nas relações sociais. São Paulo: EPU, 1965.

SENG, M. L.; WANG, R.; CHIU, A.S.F.; GENG, Y.; LIN, Y.H. Improving performance of green innovation practices under uncertainty. Journal of Cleaner Production, v. 40, p. 71-82, 2013.

SHAH, S. K.; CORLEY, K. G. Building better theory by bridging the quantitative-qualitative divide. Journal of Management Studies, v. 43, n. 8, p. 1821-1835, 2006.

SMITH, A.; VOß, J.-P.; GRIN, J. Innovation studies and sustainability transitions: The allure of the multi-level perspective and its challenges. Research Policy, v. 39, n. 4, p. 435-448, 2010.

TSAI, K.-H.; LIAO, Y. C. Innovation capacity and the implementation of eco-innovation: Toward a contingency perspective. Business Strategy and the Environment, v. 26, n. 7, p. 1000-1013, 2017. 


\section{Gestãoe \\ Desenvolvimento}

e-ISSN: 2446-6875

p-ISSN: 1807-5436

WAGNER, M.; LLERENA, P. Eco-innovation through integration, regulation and cooperation: comparative insights from case studies in three manufacturing sectors. Industry and Innovation, v. 18, n. 8, p. 747764, 2011.

WALS, A. E. J.; SCHWARZIN, L. Fostering organizational sustainability through dialogic interaction. The Learning Organization, v. 19, n. 1, p. 11-27, 2012.

WCED, U. Our common future. World Commission on Environment and Development. Oxford University Press, 1987.

YIN, R. K. Estudo de Caso: planejamento e métodos. Porto Alegre: Bookman, 2005. 